\title{
Exploring the Concept of Classical and Modern Tragedy in Peter Shaffer's The Royal Hunt of the Sun and Equus
}

\section{Azar Adil Miro}

Department of English, College of Languages, Cihan University, Erbil, Kurdistan Region, Iraq aa.miro@yahoo.com

\section{ARTICLE INFO}

\section{Article History:}

Received: 4/1/2021

Accepted: 7/2/2021

Published: Winter 2021

\section{Keywords:}

Classical tragedy,

Modern tragedy,

Catharsis.

Doi:

10.25212/lfu.qzj.6.1.35

\section{ABSTRACT}

The study of literary tragedy has become a broad literary subject since its inception in the theatre of Dionysus. However, tragedy as described by Aristotle is meant to achieve something; the result of tragedy leads to a cathartic state which is meant to purify one's soul. The process of tragic feeling brings about purgation of soul. Modern tragedy cannot be compared with the classical tragedy in terms of achieving a common goal. Tragedy in the modern time places one's soul in a state of perennial pain and eternal anguish of mind. Therefore, Peter Shaffer in his two selected plays, The Royal Hunt of the Sun and Equus, has used classical technique to explore a contemporary tragedy. The two selected plays reveal how men suffer in the modern world in a way that subjugates their souls into a depressed state. In The Royal Hunt of the Sun, men are made to suffer without deserving it. While in Equus, the psychological suffering becomes explicitly obvious. This study attempts to explore the elements of modern tragedy as they are reflected in the two texts. The thesis consists of seven main parts. The introduction overviews, the background of the study, it also explains the aim of the study, the significant of the study, research questions and the novelty of the study. The second chapter looks at the related studies about the topic. The third chapter consists of a textual analysis of The Royal Hunt of the Sun. Chapter four will be on the second drama play entitled Equus. 
The last part, the conclusion compares and overviews the whole study. The result reveals that modern tragedy is comprised of classical element of tragedy but with differences as a result of time changes. It also reveals that modern tragedy could be self-induced and it does not necessarily caused by fate as it is in classical tragedy.

\section{Introduction}

Aristotle's Poetics has given a great and interesting theoretical guideline about the tragic drama. Aristotle defines literary tragedy as "an imitation of an action that is serious and off certain magnitude; in language embellish with each kind of artistic ornament, the several kinds being found in separate parts of the play; in the form of action, not of narrative; with incidents arousing fear and pity, wherewith to accomplish Catharsis of such emotions. Every tragedy, therefore must have six parts, which parts determine its quality-namely, Plot, Diction, Thought, Spectacle, and Music". With this definition, according to Aristotle, any tragic drama that does not abide by these rules is not tragedy. Aristotle let us realize that tragedy is designed for a purpose, and the purpose is Catharsis. Tragedy is meant for the purgation of soul. Therefore, this study intends to attempt the quality of tragedy in modern drama using Peter Shaffer's The Royal Hunt of the Sun and Equus. In this sense, the nature of modern tragedy will be examined and the critical analysis of those elements of tragedy in the selected texts will be brought under focus.

As the study progresses, different techniques that the author uses in conveying his tragic message will also be touched for intellectual development. Though, the concept and the view of Aristotle are suitable for his immediate Athenian society. Looking at the guidelines given by Aristotle, it is discovered that he did not just establish his theory on the basis of assumption, but on the personal and critical study of the tragic plays written by the tragedians of the ancient times. Based on this premises, he develops the concept which is suitable for an idea tragic drama. Though, some critics and scholars have criticized Aristotle's idea of tragedy due to the concept 
of time. Aristotle critically uses Sophocles' Oedipus Rex to illustrate a good example of a perfect tragic drama.

However, the modern period tragic events are much more different from the definition given by Aristotle. But if one should critically study the quality which Aristotle states as fundamental of tragic drama one will realize that it mostly affects the nobility. Notwithstanding this study, not considering any change of time or era, we will explore tragic elements in the two plays for proper interpretation. Therefore, in the process of the study, several studies that have been previously studied will be given a close reference. Therefore, with keen focus on how Shaffer explores his tragic idea in the two texts, the study will critically be given an intellectual evaluation in order to achieve the aim through scholarly approach development of the study. In this case, the aim will be realized in a chronological order. The analysis of the texts, the use of language, and the events that arouse fear and pity as described by Aristotle will be seriously established.

\section{Literature Review}

\subsection{Introduction}

Literary tragedy has become greatly one of the most significant genres of the works of literature. Right from the Greek classical period up till now, tragedy has metamorphosed to a certain degree of intellectual development. For this reason, this study focuses on the literary and intellectual evaluation of the view on both classical and modern tragedy and how far the genre has developed from the Greek classical time this contemporary age.

Therefore, the indispensability of tragedy as established by Aristotle has something great to do with some rules and convention which have been followed by many playwrights to write their drama. In this sense, despite that the literary critic and philosopher of the Greek classical period has developed this idea for more than 2,500 years to this time, the idea still remains a very significant one in the world of literature. Though we have some literary critics of the modern time who have given contrary opinion based on the concept of time. The time in which Aristotle developed his concept of tragedy is a period that nobility and hierarchy is given a great 
importance. This contributes vehemently to the idea of having a tragic hero as a person of noble status, a king, prince, or a person of upper class in the society. Aristotle's idea is derived based on the observation and the chronological of the ancient dramatists who have written their drama passed on to the great beyond even several decades before the birth of Aristotle.

Furthermore, tragedy is identified as a universal phenomenal which every individual can go through. Using nobility as the basis, in accordance with the concept of Aristotle's theory of tragedy; if any tragedy befalls a hero in Greek society his tragedy becomes a communal tragedy. This is because his noble status affects the whole society and the members of his society feel and participates in the tragedy. This reason, the Greek tragedy is seen as the most pitiable one. The hero is seen suffering terribly by the member of the society, and becomes helpless in saving himself out of the misfortune. At this point the Greek playwrights make use of several devices to present and reveal their tragic characters, apart from language, costumes, accent, body language, stage business, physical movements, make up, marks on the body, and names that accentuate the background of the characters (Griffith Jr., 1982: 48). The most important device is dramatic dialogue. In Greek and Elizabethan plays the soliloquy is also a very popular device of characterization, and the aside is also used judiciously. A less effective style of characterization happens when characters of the play begin to comment on other characters. The actor also gives a great and significant contribution to characterization with his, inflection, intonation, facial expressions and interpretation. Although this study critically based its investigation on the written text only not the performance. It is therefore important, to acknowledge that the characters are presented and developed, by the objective they achieve, and the contribution they generally make to the performance. Although language gives one of the most important tools of characterization which determine the "general mood" of the performance. Characterization must therefore be realized mainly through the action and reaction displayed by the characters (Esslin, 1981: 39). 
Thus, Aristotle's concept of tragedy is chronologically presented in his Poetics. In the Poetics, Aristotle defines the concepts of tragic drama. For hundreds of years, many tragedians have decided to follow the Aristotle's prescription, by using them as pattern to their literary make up. Aristotle therefore defines tragedy as:

a process of imitating an action which has serious impactions, is complete, and possesses magnitude; by means of language which has been made sensuously attractive... enacted by the persons themselves and not presented through narrative; through a course of pity and fear completing the purification of tragic acts which have those emotional characteristics. (Aristotle, 1985:25).

This critical definition consists of many elements that can be critically explained in different categories and create intelligent discussions. These are: imitation, action, characters, pity and fear, catharsis. Apart from these terms, Aristotle's Poetics suggests very crucial ideas as characteristics of tragedy, which are hamartia, nemesis, anagnorisis, and pathos.

\subsection{The Components of Imitation}

The first component of the definition is 'imitation' which is in line with the Greek word mimesis and this; to Aristotle were a good terminology and an important artistic development. Aristotle sees mimesis as something that is part of human daily experience nature, which gives giving pleasure, purgation of soul, enlightening about human actions (Aristotle, 1985:20). According to Aristotle's definition, "tragedy is the imitation of an action that is serious, complete, and of a certain magnitude; it is not the imitation of an object or of a concrete element of nature". Aristotle therefore sincerely explains that tragedy is imitation through language. The work of theatre requires scenery physical, gestures actions, but the most important thing in drama is language. Stephen Halliwell is able to have a good understanding about Aristotle's idea of mimesis that is more than the ordinary imitation of similarities in nature, but with proper interpretation, a process, and a discovery of importance in the real world (Stephen Halliwell ,1986: 247). 
Aristotle's point about mimesis as a vivid representation of human life looking at its own guidelines and development, it shows the disparity with Plato's contrary opinion about drama.To Plato, mimesis is meant to deceive the audience, by persuading the audience to accept deception as their own style, in the process of teaching virtue or vice. Plato highlights that drama has too much strength to influence human behaviour, for this reason, it is too dangerous. Apart from this, according to Plato, the author can pretend to demonstrate the knowledge that he has no experience about. He could deceptively portray sometimes, a soldier, king and a mariner. The reasons Plato gives are moral (Plato, 1968: II-III, X). Giving the difference between Plato's Plato's contrary notion, Aristotle sees imitation as an instrument which is used for learning purpose and reforming character, on the basis of virtue (Nicomachean Ethics).

\subsection{Analysis of Modern Tragedy in The Royal Hunt of the Sun}

In an atteempt to give a critical analysis of The Royal Hunt of the Sun, this session will practically explore the nature of tragedy in this section as it is reflected in the text. "Save you all. My name is Martin. I'm a soldier of Spain and that's it..." (Shaffer Royal1). These words are the first words uttered by Old Martin; he is the chracter that narrates the story from the prologue to the epilogue. At the beginning of the play before developing to the exposition.

Martin emerges the stage and introduce himself to the audience and presents some crucial elements of the performance. He makes the main characters realize his age as the time he speaks. He makes himself available both inside and outside of the play.This is realised in two different forms. There is young Martin and old Martin appear in a dynamic form. As a narrator-character, he is able to present the same period of the play in different geographical locations and two different periods. Old Matin is in the period that is different from the rest of the story line.

The play starts with the coming together of a group that is going to be part of the expedition of Pizaro to a different world that is newly discovered but still not recognized. It makes the presentation of Pizarro's shimble genealogy, his skeptical 
and unstable character, his idealistic values, and his physical and mental restrictions. The group is seen arriving the New World and they meet the Incas who are the aboriginals of the New World and Atahualpa who is the Indian emperor of the Incan empire is apprehended. Therefore, the Spaniards soldiers, in their intention to take over the land murder three thousand Indians. Pizarro tries to meet with Atahualpa on a personal basis makes himself acquainted with him and creates a mutual and intimate relationship with him. For a few period of time, Pizarro tries to see Atahualpa the accomplishment of all expectations of faith and divine establishment. But this experiential phenomenon didn't have a long existence and Pizarro is found in serious perplexed situation at the end of everything. The peaceful society of the Incans is in sharp contrast with the European society in which good judgment, integrity are not obviously exhibited, but greed becomes more important. The play also increases the religious disparities between the two cultures.

At the end, quick and cruel judgment is given to Atahualpa and he is sentenced to death. But before his execution he is compelled to be baptized before he is eventually killed. This is where the tragic phenomenon begins to evolve. Nicole Ridgwa maintains that:
"Pizarro and Atahualpa's mutually destructive meeting is observed and aided by Pizarro's young page, Martin. Martin, however, speaks directly to the audience as an old man and he recounts the story of his youth. His story is of 'ruin and gold', of how 'one hundred and sixty- seven men conquered an empire of twenty-four million'. Old Martin, looking back at events in the past, provides the play with a retrospective frame. By commenting on the action that takes place on stage, he functions as the chorus 0 to the unfolding tragedy (Ridgwa, 2002: X)."

Considering this situation, the Spaniards soldiers invade the Incan empire and forced them to become Catholics. Their intention is never a good one. When one takes a critical consideration of the situation of the invasion, it becomes clear that the intention of invading the land is for personal interest not for divine purpose. The Incans have their own religious value before the arrival of the Spaniards, but the 
Spaniards see their practice as act of paganism and this leads to them forcing the entire empire and the emperor to become Catholics and be baptized. The richness of the Incan cultural value goes into extinction. All their precious treasures such as gold are looted by the Spaniards who claim to have brought them a new religion; the light of God. Their attitude towards the Incans and their emperor is horrific.

At the end of the play, innocence disappears and faith is placed in instead of unbelief. Old Martin gives information about the final days of Pizarro and the changes that have taken place in his soul, the disillusionment of his spiritual state, and the material achievements and the root of the life of the people of Peru. The play then ends with the death of Atahualpa who eventually dies at the feet of Pizarro. Pizarro therefore consequently sings a dirge those talks about a little finch that is caught in a trap. The Royal Hunt of the Sun reflects great various theatrical development which is well manipulated and it leads to a complete spectacle of a good dramatic text, an intelligent visual quality that enhance seriously the quality of the text. The quality of the text is then enhanced due to the inclusion of the sound track and music in order to establish a tragic mood. Peter Shaffer's plays give the significance of both aura and visual aspect of the dramatic text. Though the play has the content of history and which is brilliantly it crafted. Harbi explains that

However, the importance of the visual and aura elements of the play;Peter Shaffer uses language very carefully. He chose to use prose instead of poetic dialogue. Although the men of Pizarro make use of conversational language that includes cursing and slang, such as VacasVascas - ^“You're pissing right!" (5)—, Rodas-^“Just you

The play has the expression of foreign language such as spanish words and and names. Latin and the quotations of the Bible, Indian expressions and some words that are and not translated into English. The foreign phrases and expressions reveal that the setting of the play is in a remote location and period and this gives one some conviction and plausibility of its appropriateness. It also shows the problem language can develop and how important it could be. When Manco shows up and begins to talk in Spanish, the Indian language becomes obvious and Felipillo gives an interpretation 
in English (19). The Indian language is greatly enhanced by the use of mime. Young Martin reveals his importance in the major two languages; that is the Indian language and the Spanish language. Though some critics criticized The Royal Hunt of the Sun as being poor in dialogue and too exaggerating in terms of visual and aural aspect. While some other critics also claim that "it was too spectacular, too lavish at the expense of dialogue and character" (Graham-Adriani ix). Shaffer's drama, therefore does not understimate the value of language which gives clarity, logics and understanding.

It also gives necessary values. This is reflected in dialogues between Pizarro and Atahualpa. Dialogue is an important element that enhances the quality of a play. Take for instance tragedy; dialogue is usually used to heighten the effect of the tragic drama. However, an extensive dialogue and soliloquies are not common in the play but there is a conversation that Pizarro immediately after his critical predisposition in front of Atahualpa. He reflects his lamentable situation about the destructive power of Time and Death against the young ones of life (62-63), and he gives an announcement of the death of Atahuallpa that it will come soon (63). The concern of Pizarro has to do with the unavoidability of death. This is reflected in his speech where he says: "Atahualllpa, I'm going to die! And the thought of that dark has for years rotted everything for me, all simple joy in Ufe" (63).

Here, tragedy is revealed and the effect of it becomes serious. Dialogue becomes very essential in that enhances the effect of tragedy as he makes the dialogue. In this regard, the dialogue makes one feel and have some sense of sober reflection. Tragedy is mainly felt when the use of language is effectively conveyed. Peter Shaffer makes use of dialogue in an effective manner. The despodent Pizarro is able to have a good understanding about the concept of time and death. In this case, there is consolotion to the sorrow of Pizarro. The tragic situation surrounding his ordeal becomes unchangeable. Dawson maintains that, performance in theatre has to with, "movement, gesture, properties and scenery are auxiliaries which, ideally speaking, should grow out of die creative language" (Dawson Drama and the Dramatic 8).

Therefore, in The Royal Hunt of the Sun, characterization becomes a very complex factor that involves various traditions. Therefore the dialogue of every character, the 
connection between the characters, movement, physical deficiency, costumes and make-up, even visual and sound effect which re-enhances the traces of character, like all the lighting effects and the sound track of music inspiring Atahualpa with some effect of divinity. Stephens maintains that:

This, therefore, dignifies the beauty of the play to the extent that the illusion is clearly brought to life. Most important thing about a dramatic text is that it creates room for visual beauty in the sense that the world predicted in the text is realized in its scenic form.

\section{4 "The Hunt" and "The Kill".}

The Royal Hunt of the Sun is fragmented into two parts; that is"The Hunt" and "The Kill". And every part is segmented into twelve scenes. There is no pause between the scenes in the sense that each scene follows each other constantly, as the author himself explains in his note (Shaffer Author's Notes xii). The structure of the play is understably simple, and the segmentation suggests that the heart of the play is the character of Atahuallpa, his capture and execution. Moreover, the play is also very concerned about Pizarro's internal and external conflicts: his mentalorder, his encounter with Atahuallpa, and the crucial companionship of cordial trust they develop for each other.

In the exposition scene that is specifically presented by Old Martin, the major characters are presented, the place and period are established, the atmosphere of disillusionment is conveyed. The structure of the play is patterned in accordance with the historical record of the Peru conquest, the expedition preparation, the coordination of the group under the headship of Pizarro, the consecration of their amunition, their leaving the Spain, the arrival in America,capture, the climbing of the mountains, and execution of Atahuallpa, and the narrow escape. Clearly, when one considers the complexity of such a representation in the theatre, no scene of their voyage in made through the sea. In the exposition part, the Narrator presents himself and the most crucial conflicts, giving the setting, the infirmity of Pizarro and elements of his character. 
The climatic situation of the play takes place at the time Pizarro goes the tragic dilemma of whether to release Atahuallpa or not, subsequently followed by his falling and surrender to the character of Atahuallpa, Pizarro'inability to have control over his subordinates, his loss of power, and Atahuallpa'execution. After that, the hero collapses over the body of the Inca, in tears and lamentable agony, as if Atahuallpa's death symbolises his own demise, or the death of the last expectation of his life, the expectation that the world can be better, and that human beings can overcome the power of time and death. In this sense, the tragic phenomenon that reveals itself revolves around the execution of Atahuallpa and the death of Pizarro.

When tragedy becomes a communion one, it affect the whole entire community becaus the person involved is a noble person. Considering the tragic experience in this play, in accordance with Aristotle's concept, one will discover that the two heros concerned are persons of noble status: Atahuallpa is an emperor while Pizarro is an army General. Therefore, the play also gives answer to some critical issues of the modern time.Ridgwa postulates that:

However, the scene presents the ruin of Atahuallpa's life and kingdom, the fall of Pizarro, his hope and dignity, followed by his identifying of the of the woe in which he is directly involved.The bird's image functions as an allegory in the play, which has many references to birds: the bird's cry in the forest, the finch song that by Atahuallpa sings in the middle of the play and by Pizarro at the sequencial end of the play. Atahuallpa himself symbolizes the exotic bird.This can be exemplified in the attire of Atahuallpa which are made of feathers of birds (46). The bird's cry intensifies the effect of the most crucial and the tragic scenes, like when the Spanish are at Cajamarca, when they are surrounded by Indians at the middle of the night and the birds haimted at them(15). Pizarro regards himself as a free bird; but Atahuallpa captures his heart consequently. When Atahuallpa receives Pizarro's confession in an Indian ritua rite, Pizarro reacts with a very uncommon blessing, which shows thatAtahuallpa's death is close and establishing the type of close relation they have had. It also suggests some kind of hope Pizarro has had about resurrection of Atahuallpa: "If any blessing is in me, take it and go. Fly up, my bird, and come to me 
again" (76). In the last scene of the play, Pizarro sings the bird's song that falls into a trap, that refers to both the capture of Atahuallpa and his death (79-80).

All these are the predominant factors that add more effect to the tragic phenomenon of the text. Therefore, all the circumstances that surround the tragedy of Atahuallpa and Pizaro calls for tears and fear. As Aristotle postulates that the tragic effect is more experienced in text when one sees a hero who goes through so much pain and anguish beyond the offence he has committed. Though, being rigid and dugmatic to one's belief could be seen as a flaw in Atahuallpa'scharacter, but he dies as a result of what he stands for. Seeing Atahuallpa in such a pathetic situation arouses fear and pity as explained by Aristotle. When one takes a critical look at the situation, it becomes more pathetic in the sense that Atahuallpa's land is invaded by the spaniards who come in the name of religion but with a ultirior motive to loot their treasury of gold. Rocognizing this situation, one is compelled to shed tears and feel for Atahuallpa for he suffers a lot for what he staands for.

However, when the spaniards try to convert Atahualpa to Christianity, he bluntly refuses and he claims he serves a god that never once fails him. He makes them realize his devotedness and commitment to the Sun-god for decades and he denies the God of the Spaniards. Meanwhile, if one looks critically into the situation of the conversion that the Spaniards are trying to make, it becomes certain that their aim is not particularly for true piety but for the purpose stealing their treasure. Atahualpa rejects the religion of the Spaniards.

\section{ATAHUALLPA:}

"No! He is not true...Where is he? There is my Father-Sun! You see now only by his wish; yet try to see into him and he will darken your eyes forever! With hot burning he pulls up the corn and we feed. With cold burnings he shrinks it and we starve. These are his burnings and our life. Do not speak to me again of your god. He is nowhere. (63)" 
Atahualpa therefore rejects the God of the Spaniards despite their attempt to persuade or force him to accept Him. He tries to prove some logics about a visible god. The god you can see and feel. For this reason, he exclaims that he doesn't need the Spaniards God that He does not exist; he is nowhere. This could have been the beginning of Atahualpa doom. As Aristotle explains, that a tragic hero must have a hamartia and that hamartia makes him make an expensive error that usually leads to his terror. Atahualpa harsh response to the preaching of the Spaniard could have been seen as an error. Making an error without noticing it is always peculiar to the character of a tragic hero. The hero therefore, tries to personally make contribution to his personal doom.

Considering the error of Atahualpa, in relation with the dialogues between him and Pizarro stated above, one will realize that Atahualpa as a tragic hero has also once committed a grievous error which he takes for granted. Pizarro makes it clear to him that the throne of power and authority he occupies is not legitimately meant for him but for his brother. But because he feels a Sky-god which he refers to as his father has instructed him to overthrow his brother and he assassinates him and takes over his rightful throne. He says that the Sky-god tells him that his brother is meant to tend herds while the throne is meant for him.

This is what he uses to justify his act of murder. Tragic conflict therefore evolves here. Aristotle talks about tragic conflict as a conflict that occurs where conflict is not supposed to occur. Such as the conflict between father and son, conflict between husband and wife, between mother in-law and daughter in law and between brother and brother just like it happens between Atahualpa and his brother. Shafer follows Greek classical guideline in presenting his text and this is well reflected as Nicole Ridgwa states that:

"Given his interest in worship and belief, and in the relationship between individual choices and the larger social or moral order, it is not surprising that Shaffer also draws on (and expects his audience to know something about) the theatrical tradition of classical Greek tragedy. The similarities to this theatrical form can be seen in Shaffer's use of: ritualized lements 
and a stylized approach to dialogue and physical movement; a central character who is 'larger than life'; and a moral and political order in which the characters' lives and actions are constrained(Ridgwa, 2000: XXXVIII)."

This tragic conflict leads to the grievous error committed by Atahualpa by killing his brother an takes over his throne. The beginning of the tragedy of Atahualpa can be traced to that incident of murder. Even when Pizarro makes him realize it, despite their intimate relationship, he doesn't listen to him, rather he justify his act. In this regard, Atahualpa as a tragic hero has a flaw that digs his grave. When the recognition surfaces, the hero becomes aware of his error as it happens in Sophocles' Oedipus Rex. When king Oedipus is aware of his error, he realizes that he also contributes to his own doom. Though, Atahualpa reflects the tragedy of modern tragedy but he possesses the qualities which Aristotle explains that a tragic hero must possess before he can attain the position of a person to be called tragic hero.

\subsection{The Hero and His Tragic Flaw}

Therefore, in classical Greek period, the gods look for an error or weakness to capture a hero. The hero must be guilty for a particular offence and he must be punished for it. It does not matter how innocent the hero may be, he must get retribution for his error. In Greek tragedy, ignorance is not an excuse to an error. Once you trespass against the gods they take their pound of flesh. The Greek gods don't forgive. But in the process of trying to punish the offenders; the gods make the hero go through the pain and agony that he doesn't deserve. For this reason, the hero gains sympathy and the empathy from the people and these arouse fear and pity.

In Atahualpa case, his error is one of the things that are used to condemn him. Though his baptized, but he dies a painful and tragic death. The Spaniards overthrow him and his end is brutal. Considering the situation of Atahualpa and Pizarro. Their relationship is a cordial one; even in death they both maintain companionship. However, the way the whole situation begins and ends provokes tears and compassion. He is charged and tried: 
"OLD MARTIN: The Inca was tried by a court quickly mustered. He was accused of usurping the throne and killing his brother; of idolatry and of having more than one wife. On all these charges he was found-

ESTETE: Guilty.

VALVERDE: Guilty.

DIEGO: Guilty.

OLD MARTIN: Sentence to be carried out the same night.

ESTETE: Death by burning.

PIZARRO: No! He must not burn! His body must stay in one piece!

VALVEDER: Let him repent his idolatry and be baptized a Christian. He will receive a customary mercy.

OLD MARTIN: Strangling him instead.

PIZARRO: You must do it! Deny your father! If you don't, you will be burnt to ashes. There will be no flesh left for him to warm alive at dawn...You must do it.

OLD MARTIN: So it was that Atahualpa came to Christ.

DENIZZA: I baptize you Juan de Atahualpa, in honour of Juan the Baptist, whose sacred day this is.

ESTETE: The twenty-ninth of August 1533.

VALVERDE: And may Our Lord and His angels receive your soul with joy! SOLDIERS: Amen!

ATAHUALPA: INTI! INTI! INTI! 
VALVERDE: What does he say?

PIZARRO: The Sun. The Sun. The Sun.

VALVERDE: Kill him! (88-89)."

This is how Atahualpa ends. He takes a slippery path, he is very unfortunate and he never finds mercy in the sight of any one. He is found guilty of many offences, and he is tried and condemned. In this sense, he deserves death. He is required to renounce his idolatry and obtain a customary mercy. But instead, he stands on what he believes and dies for it. The end of Atahualpa gives another form of tragic feeling and purges one's soul. As Aristotle explains that tragedy must be able to achieve a specific purpose, and that is Catharsis; there must be a process of purification in man's soul which could be termed "tragic relief". When the purification has taken place then the relief occurs.

Atahualpa ends tragically in the sense that his past error catches up with him and he pays seriously for it. One should ask some questions that if Atahualpa had renounced his adulatory as requested by the priest, and receive pardon, would tragedy have evolved. Of course there will be no tragedy again. His adamant decision never to renounce his belief in his personal religion also helps the tragedy to come to stay apart from the crime of killing his brother. Atahualpa falls so is his empire.

\section{Conclusion}

In conclusion, this study has been able to examine the main elements of tragedy both in classical and modern contexts and the result is that tragedy is not peculiar to a certain selected few, the people of upper class--the so called noble figures. But it is a phenomenon that is universally peculiar to every individual, noble or not, upper class or average class. The study explores and analyzes the tragic phenomenon of The Royal Hunt of the Sun and how the entire Incan Empire is subdued by the Spaniards Army. The hero's fault and his doom are critically evaluated. In chapter 
four, the text is examined in accordance with modern tragedy, and the result reveals that tragedy is not peculiar to only the upper class but also to the common people. The commonest people can as well go through a process of tragic experience even beyond what the noble people can endure.

Therefore, the findings of the study reveal that Peter Shaffer has made use of the guidelines of the Aristotle concept of tragedy at the same time, in order to make sure that he fulfils the modern concept of tragedy, he applies Arthur Miller's tenet. As he applies Aristotle's concept of tragedy in The Royal Hunt of the Sun making the noble figure a tragic hero so he applies Arthur Miller's concept of modern tragedy to portray an ideal modern tragedy. He uses a common people to establish the authenticity of modern tragic figure. Therefore, the essence of this study is that the style that Peter Shaffer has used to reflect tragedy in real sense is dynamic and full of artistic aestheticism. If one should consider the beauty of literary tragedy, it is in the style of the author. However, it is important to note that style in dramatic text is in different forms. There is always styles in the plot structure, language, speech, costume, make up even in the narration. The prologue and epilogue could also be given a style that demands logical view.

In this respect the way Shaffer has dynamically reflected tragedy in the two texts gives one an awareness of how one should understand literary tragedy be it in classical or modern context. Therefore, Shaffer has made us understand that tragedy goes beyond its physicality but it has something very crucial to do with what happens in life and in the society of men and their world of spirituality. The spiritual state of Alan and his psychological imbalance provide some clues to what really happens in the metaphysical realm. Considering the two texts and their contextual exploration and interpretation, it becomes evident that the understanding and interpretation of tragedy could be subjective and objective. Critically speaking, tragedy is dramatic genres that makes one feel rather than think. Tragedy has some purifying antidote to the depressive moment that occurs during the process of viewing

Thus, the study summarizes the whole study and the findings of the study are stated. Using a contextual method as an approach by giving a textual analysis of the 


\section{QALAAI ZANISTSCIENTIFIC JOURNAL \\ A Scientific Quarterly Refereed Journal Issued by Lebanese French University - Erbil, Kurdistan, Iraq \\ Vol. (6), No (1), Winter 2021 \\ ISSN 2518-6566 (Online) - ISSN 2518-6558 (Print)}

two texts, many discoveries are made which give the study some intellectual development. The study of literary tragedy has been thoroughly explored for many centuries, but it is essential to make more research in order to keep finding some new discoveries. It is therefore good that the research scholars and students of literature make more research on Peter Shaffer's concept of tragedy as he has always expressed it through his drama. This however will give more information about Shaffer's nature of tragedy.

\section{REFERENCES:}

Aristóteles. Ética a Nicômacos. Trad. Mário da Gama Kury. 3. ed. Brasília; Editora Universidade de Brasília, 1985.

Bames, Jonathan (ed). "Life and Work." The Cambridge Companion to Aristotle.

Cambridge: University of Cambridge Press, 1995. pp. 1-26.

Bames, Jonathan (ed). "Rhetoric and Poetics." The Cambridge Companion to Aristotle. Cambridge; University of Cambridge Press, 1995. pp. 259-85.

Bamet, Sylvan et al. Types of Drama: Plays and Essays. Glenview: Scott, Foresman and Company, 1988.

Bentley, Eric. Theatre of War: Modern Drama, From Ibsen to Brecht. New York; The Viking Press, 1973.

Bible, King James Version. London: Trinitarian Bible Society, 1992.

Bittner, Rüdiger. "One Action." Essays on Aristotle's Poetics. Ed. AmélieOksenbergRorty.

Princeton: Princeton University Press, 1992. pp. 97-110.

Boal, Augusto. "Aristotle's Coercive System of Tragedy." Tragedy. Ed. John Drakakis and Naomi Conn Liebler. London; Longman, 1998. 123-140.

Bomheim, Gerd. O Sentido e a Máscara. São Paulo: Perspectiva, 1975.

Boulton, Maijorie. The Anatomy of Drama. 9th. ed. London: Routledge, 1988.

Brandão, Junito de Souza. TeatroGrego: Origem e Evolução. São Paulo: ArsPoética, 1992.

Brandão, Junito de Souza. TeatroGrego: Tragédia e Comédia. 6 ed. PetrópoHs: Vozes, 1985.

Brockett, Oscar G. The Theatre: An Introduction. 4th. ed. Chicago: Hoh, Rinehart and Winston, Inc., 1964.

Cooke, Virginia, and Malcohn Page, comp, and eds. File on Shaffer. London: Methuen, 1987.

Dawson, S. W. Drama and the Dramatic. London: Methuen, 1984.

Drakakis, John, and Nami Conn Liebler (ed.). Tragedy. London: Longman, 1998.

Drakakis, John, and Nami Conn Liebler (ed.). Introduction. Tragedy. Ed. John Drakakis and Nami Conn Liebler. London: Longman, 1998.

Else, Gerald Frank. The Origins and Early Form of Greek Tragedy. Cambridge: Norton, 1965. 
Else, Gerald Frank. Notes. The Origins and Early Form of Greek Tragedy. By Else. Cambridge: Norton, 1965.

Else, Gerald Frank. Introduction. The Origins and Early Form of Greek Tragedy. By Else.

Cambridge: Norton, 1965.

Euripides. The Plays. Trans. Edward P. Coleridge. Chicago: Encyclopaedia Britannica Inc., 1965.

Gianakaris, C. J. Peter Shaffer. Ed. Bruce King and Adele King. London: Macmillan, 1992.

Girard, René. A Violência e o Sagrado. Trad. Martha ConceiçãoGambini. São Paulo: Paz e Terra e Editora UNESP, 1990.

Graham-Adriani, Suzy. Introduction. The Royal Hunt of the Sun. By Peter Shaffer. London: Longman, 1964. viii-xi

Griffith, Jr., Kelley. Writing Essays About Literature: A Guide and Style Sheet. San Diego: Harcourt Brace Jovanovich Publishers, 1982.

Halliwell, Stephen. Aristotle's Poetics. Chapel Hill: University of North Carolina, 1986.

Shaffer, Peter. The Royal Hunt of the Sun. London: Longman, 1991.

Shaffer, Peter. Equus. Harmondsworth: Penguin Books, 1974

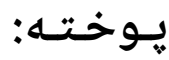

ئهدهبياتى ترازيديا بوهته بواريّكى فراوانى لِيكوَّلَينهوه ههر له سهرهتاى دروستبونيهوه له شانوّكانى

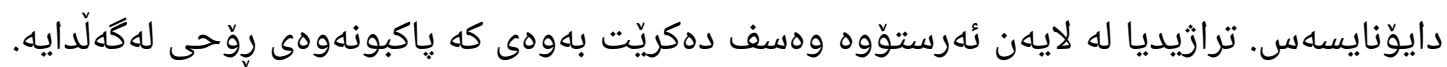
ترازيدياى موّديّرن ناتوانريّت بهراورد بكريّت به ترازيدياى كلاسيك له روى بهدهستهيّنانى ئامانجيّكى هاوبهش. ترازيدياى موّديّرن روّحى كهسهكان دهخاته ئازار يّكى ههميشهيى و ميّشكيشيان دهخاته

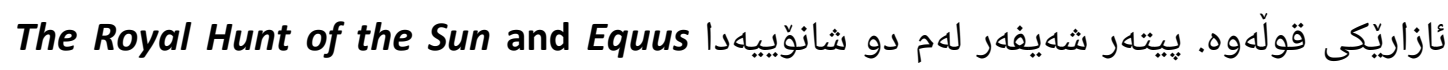
ته كنيكى كلاسيكى بهكارهيّناوه بوّ لِّكوّلَينهوه له ترازيدياى سهردهم. ئهم دو درامايه ئهوه دهردهخهن

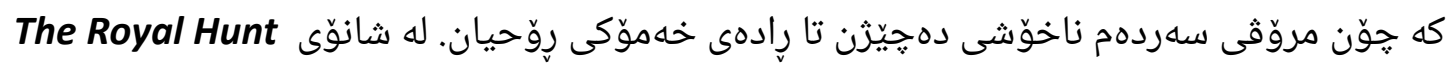
مروّق ناخوّشى دهجه زيّت به بي ئهوهى شايهنيشى بيّت. له شانوّيى Lf the Sun

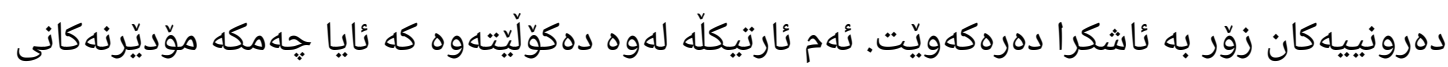
ترازيديا جين و جوّون لهم دو شانوّييهدا رِنكيان داوهتهوه. 


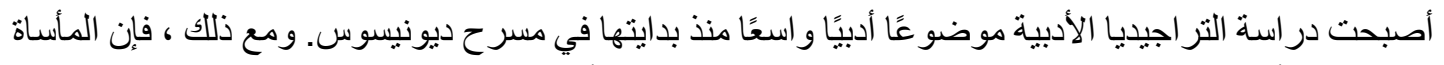

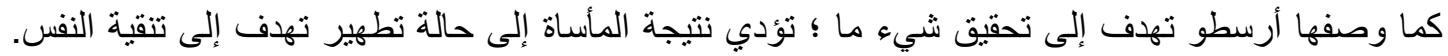

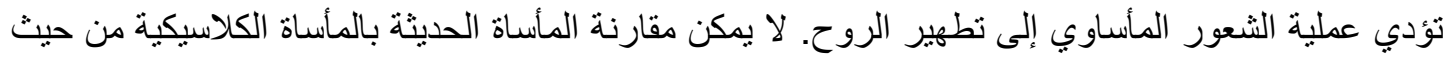

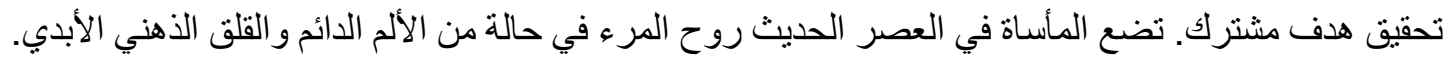

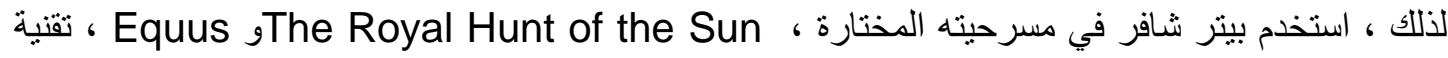

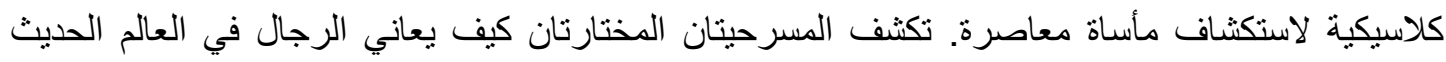

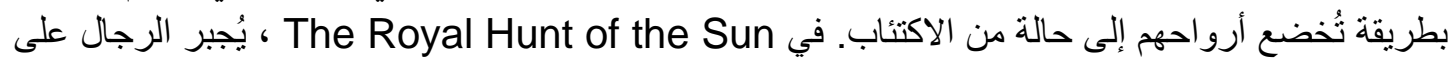

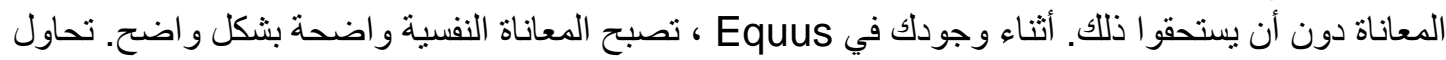
هذه الدر اسة استكثاف عناصر المأساة الحديثة كما وردت في في النصين. 